
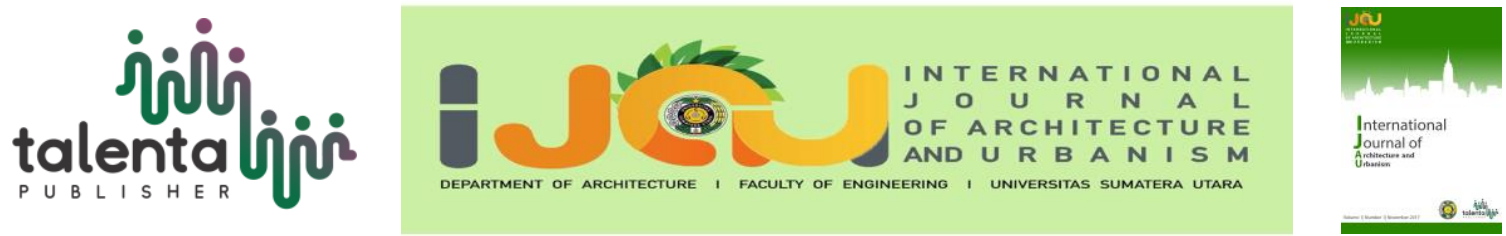

\title{
Analysis of Fire-fighter Access as Protection against Fire Hazard in High-rise Building
}

\author{
Niswa Dewi A', Vinky Rahman ${ }^{1}$ \\ ${ }^{1}$ Architecture Department, Faculty of Engineering, Universitas Sumatera Utara, Medan, \\ Indonesia
}

\begin{abstract}
There have been many cases of fire in high-rise building occurring in the world taking a lot of casualties, some of them are the World Plasco Building in Tehran, the Grenfell Tower in London, and the Cosmopolitan of Las Vegas in Las Vegas. One of the problems that arise in many cases of fire in a high-rise building is the difficulty of access for firefighters to control fire. According to these cases, it is crucial to analyse further the access of firefighter in a high-rise building as protection against fire hazard. The study aims to find out how to assess the reliability of the fire fighting access, water supply, access aperture, and shaft of the firefighter in a high-rise building as protection against fire hazards by using the Analytical Hierarchy Process (AHP) which is sufficient to solve the problems of the reliability level of firefighters access in a high-rise building. The result is that the access of firefighter in the high-rise building on the Good level of reliability. Therefore, to improve the results of the reliability value of firefighters access in the high-rise building to be better by giving some design recommendations which according to the requirements of firefighters access. Meanwhile, the researchers can use these results of the study as reference and information for future research.
\end{abstract}

Keyword:fire, access, high-rise building, protection, system

\section{Introduction}

Fire is a catastrophic event which unwanted that can cause material and non-material losses. Fire hazards can occur anywhere in big cities with a high population density, especially the threat of fire in high-rise buildings whose cases have already taken place in the world. Among them is the World Plasco Building in Tehran, the Grenfell Tower in London, and the Cosmopolitan of Las Vegas in Las Vegas. One of the problems caused is the difficulty of access for firefighters to control fire.

This research aim was to analyse firefighters access as protection against fire hazards in highrise buildings. The case study taken was one of the high-rise building in Medan City, Cambridge the Luxurious Mall and Condominium, which is one of the high-rise buildings in Medan city that has a mixed-use function which is as a residential, shopping centre and office,

*Corresponding author at:Departement of Architecture, Faculty of Engineering, Universitas Sumatera Utara, Street Perpustakaan Building J07, Medan, Indonesia

E-mail address: niswadeaprlyn@gmail.com 
also classified as user-intensive and located in densely populated areas. Therefore, it is necessary to have access to firefighters that are following standards so that the fire disaster management process can be handled easily by firefighters.

\section{Literature Review}

Based on the definition of the NFPA (National Fire Protection Association) and Dewan Keselamatan dan Kesehatan Kerja Nasional (DK3N), a fire is an oxidation event involving three main elements; they are combustible fuel, oxygen, and a source of energy or heat. Fire causes an unwanted that can cause harm, both material losses (in the form of property, physical buildings, facilities, and infrastructure) and non-material damages (such as fear, trauma) to injury and death [1].

According to Permen PU No. 26/PRT/M/2008 concerning Technical Requirements for Fire Protection Systems in Buildings and the Environment, what is meant by a fire protection system is one or a combination of methods used in a building to warn people of emergencies. Alternatively, the provision of a place of rescue (evacuation), or limit the spread of fires, or fire prevention and suppression, including here passive and active fire protection systems [2].

According to Permen PU No. 20/PRT/M/2009, areas that have been built and inhabited must be protected by fire truck whose closest post is within $2.5 \mathrm{~km}$ and is $3.5 \mathrm{~km}$ from the Fire Management Area sector [3].According to SNI 03-1735-2000, the availability of fire fighting access points which include road vehicles, roads for fire fighting, or a combination of these roads that can access each side of the building. The minimum width is $6 \mathrm{~m}$, and the length is 15 $\mathrm{m}$, with the hard-standing to the building is $2 \mathrm{~m}$, and the maximum is $10 \mathrm{~m}$. The hard-standing of the access point must not exceed $46 \mathrm{~m}$, and if it exceeds $46 \mathrm{~m}$, it must provide the turn facilities. The outermost radius of the turn in the entry point must not be less than $10.5 \mathrm{~m}$ and must meet the requirements [4].

Meanwhile, also according to SNI 03-1735-2000, the hard-standing on each side of the building are available specifically or by using public roads, with no obstruction, with a minimum height of free space on the hard-standing or firefighters entry point is $4.5 \mathrm{~m}$. The slope should not exceed 1: 8.3. The hard-standing must be made of metal, paving blocks, or reinforced layers. There are markers on the four corners of the hard-standing area for the firefighters with contrasting colours and are reflective so people can see the inlet and hard-standing at night.

According to SNI 03-1735-2000, Siamese connections are available on firefighters access points and city hydrants with a maximum distance of $50 \mathrm{~m}$, if there is no yard hydrant. If there are more than a yard hydrant, the yard hydrant must be within a maximum radius of $50 \mathrm{~m}$ from the fire department access point. 
According to Permen PU No. 20/PRT/M/2009, water supply for fire fighting needs can be obtained from a natural amount such as water ponds, lakes, rivers, rapids, deep wells and irrigation channels, as well as artificial water tanks, gravity tanks, swimming pools, fountains, reservoirs, water tankers and hydrants.

According to SNI 03-1735-2000, the size of firefighters access aperture is at least $85 \mathrm{~cm}$ wide and $100 \mathrm{~cm}$ high, with a maximum threshold height is $100 \mathrm{~cm}$ and a height of the upper threshold of at least $180 \mathrm{~cm}$ above the inner floor surface. The sign is given red or yellow triangle signage with a minimum size of $150 \mathrm{~mm}$ each side and given the words "FIREFIGHTERS ACCESS - DON'T BLOCK" with a minimum height of $50 \mathrm{~mm}$, in high-rise buildings that are limited and difficult to open access, it must be equipped with an internal fire extinguisher.

According to SNI 03-1735-2000, the minimum number of shafts for firefighters in buildings that are installed with automatic sprinklers with a floor area more than $2000 \mathrm{~m}^{2}$ is two shafts and is plus 1 for each addition of $1500 \mathrm{~m}^{2}$. The distance between the shaft lobby and the access door of firefighters is not more than $60 \mathrm{~m}$. Fire lifts and fire stairs equip for each shaft of firefighters that are following the requirements, as well as the main water supply for extinguishing that has outlet connections and valves in each lobby fire suppression except at the access level.

Based on the Minister of Public Works Regulation No. 20/PRT/M/2009 concerning Technical Guidelines for Management of Urban Fire Protection, the response time of Fire Fighting Agencies for fire notifications for conditions in Indonesia not more than 15 (fifteen) minutes. The time starts from the receipt of notification of a fire in a place, the determination of the location of the fire, information on the burning object and the preparation of troops and facilities for extinguishing, travel time from the fire station to site, and equipment preparation time on site until ready for spraying operations.In the Standard Operational Procedure (SOP) of each Firefighter Agency regulate the series of fire management procedures [5].

According to the Emporis Standard (ESN 18727), high-rise buildings are architectural structures or buildings with a height of more than $35 \mathrm{~m}$ or several floors of at least 12 levels [6].Analytical Hierarchy Process(AHP) is a decision support model developed by Thomas L. Saaty. This decision support model will describe complex multi-factor problems into a hierarchy. A hierarchy can explain a complex problem into groups which arranged into a hierarchical form so that the issues will be more structured and systematic [7].

\section{Methodology}

The study uses the descriptive method that would explain the existing conditions of firefighters access to the Cambridge the Luxurious Mall and Condominium building by direct observation. 
Whereas to analyse the data, the research methods are the qualitative and descriptive analytic of the quantitative, which will compare the observation data on the variables in the case study with the prevailing theories and standards.

Determination of variables and sub-variables are from SNI 03-1735-2000 concerning Planning Procedures for Building Access and Environmental Access to Fire Hazard Prevention in Buildings. The following stages of data processing in assessing the reliability of fire-fighting access in Cambridge the Luxurious Mall and Condominium buildings using the AHP (Analytical Hierarchy Process) method. First is sorting variables and sub-variables based on their importance. Then, calculate the percentage of weight for each variable and sub-variable the calculation of weighting percentage by reference to the Interest Scale (Table 1). Then, determine the Availability Value of each sub-variable in the case study (Table 2).

Table 1. Variable and Sub-variable Interest Scale

\begin{tabular}{cl}
\hline Value & \multicolumn{1}{c}{ Explanation } \\
\hline 1 & A is equally important with B \\
\hline 3 & A is slightly more important than B \\
\hline 5 & A is definitely more important than B \\
\hline 7 & A is very clearly more important than B \\
\hline $2,4,6,8$ & A is absolute more important than B \\
\hline
\end{tabular}

(Source: Saaty, 1998)

Table 2. Sub-variable Availability Value in the Case Study

\begin{tabular}{cc}
$\begin{array}{c}\text { Reliability Value of Sub- } \\
\text { Variables in the Case Study }\end{array}$ & Explanation \\
\hline 1 & It has absolutely no components according to the reliability \\
requirements
\end{tabular}

Then, calculate the Reliability Value. Multiply the sub-variable weight with the value of the availability of sub-variables in the case study. Then add all the sub-variables in each variable to get the reliability values for each variable. Moreover, multiply the weight of each variable to get the final of the reliability of the fire-fighting access in the Cambridge the Luxurious Mall and Condominium building. The conclusion is obtained by referring to the following reliability scale (Table 3). 
Table 3. Reliability Value Scale of Fire Fighting Access

\begin{tabular}{cc}
\hline Reliability Value & Explanation \\
\hline $1,00<\mathrm{x} \leq 1,60$ & Bad \\
\hline $1,60<\mathrm{x} \leq 2,20$ & Deficient \\
\hline $2,20<\mathrm{x} \leq 2,80$ & Sufficient \\
\hline $2,80<\mathrm{x} \leq 3,40$ & Good \\
\hline $3,40<\mathrm{x} \leq 4,00$ & Excelent \\
\hline
\end{tabular}

\section{Result and Discussion}

Research Location Data: Cambridge the Luxurious Mall and Condominium

The area of research wasa high-rise building in Medan city with mixed-use functions (shopping centres, offices, hotels and apartments) located on Jalan S. Parman, Medan City, North Sumatra, Indonesia (Figure 1). This building consists of 4 towers with the number of floors on three towers as many as 26 levels and one tower as many as 27 floors and stands on a site of approximately $8500 \mathrm{~m}^{2}$ (Figure 2).

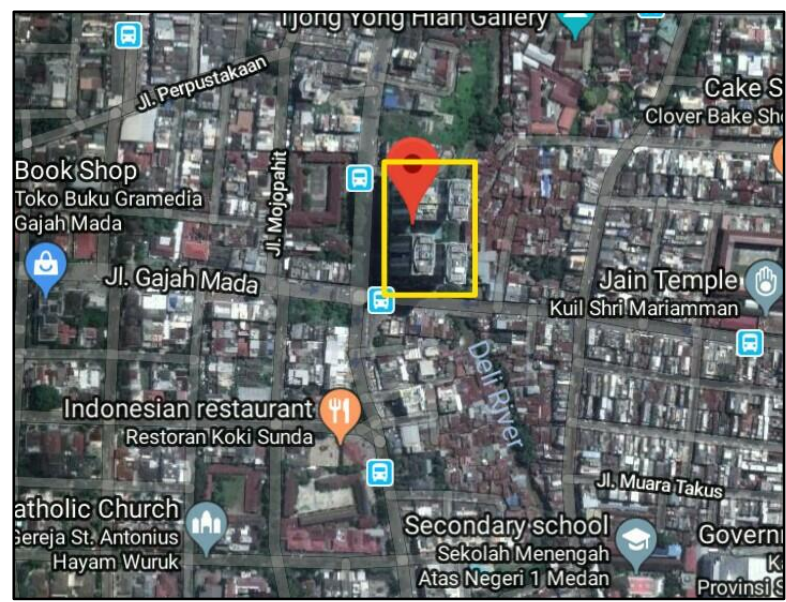

Figure 1.Research site maps

(Source: https://earth.google.com) 


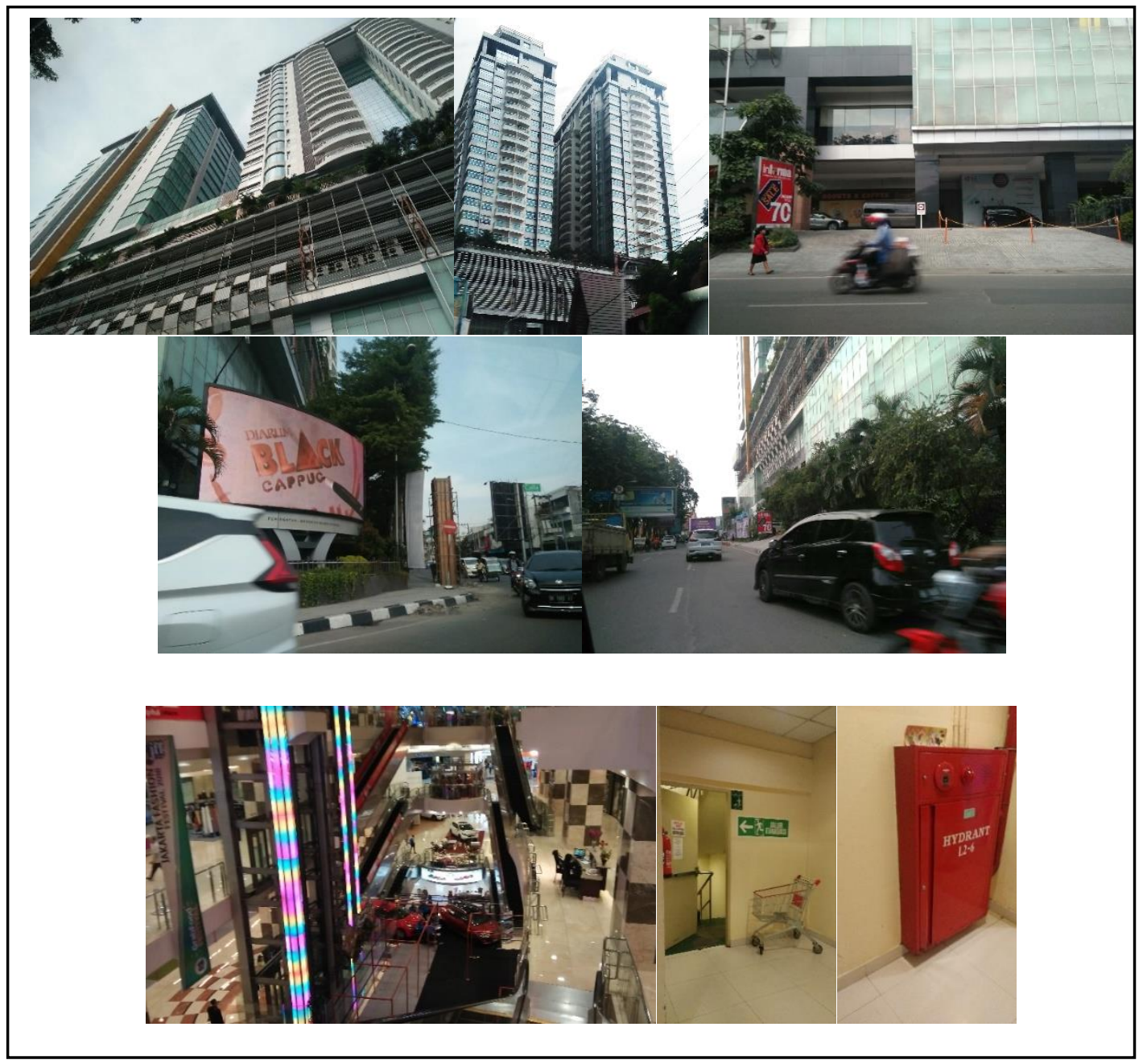

Figure 2.Cambridge the Luxurious Mall and Condominium

As for the results of processing the AHP Method with MS Application Office Excel based on the sequence of work steps is, first, sort each variable and sub-variables by the interest sequences (Table 4) (Table 5).

Table 4. Table of Interest Sequences for each Variable

\begin{tabular}{ccc}
\hline Serial Number & Code & Variable \\
\hline 1 & A & Fire Fighting Access \\
\hline 2 & B & Water Supply \\
\hline 3 & C & Fire Fighter Access Aperture \\
\hline 4 & D & Fire Fighter Shaft \\
\hline
\end{tabular}


Table 5.Table of Interest Sequences for each Sub Variable

\begin{tabular}{ccl}
$\begin{array}{c}\text { Serial } \\
\text { Number }\end{array}$ & Code & Sub Variable \\
\hline & & \multicolumn{1}{c}{ A. Firefighting Access } \\
\hline 1 & A1 & Distance and travel time from the nearest fire station \\
\hline 2 & A2 & Firefighting access road \\
\hline 3 & A3 & Hard-standing Availability \\
\hline 4 & A4 & Height of free space and slope of hard-standing \\
\hline 5 & A5 & Material of hard-standing \\
\hline 6 & A6 & The outer radius of the turn, the size, and the distance of the hard-standing \\
\hline 7 & A7 & Hard-standing signage \\
\hline & & B. Water Supply \\
\hline 1 & B1 & Alternative fire fighter water supply \\
\hline 2 & B2 & Outdoor hydrant \\
\hline 3 & B3 & City hydrant and siamese connection \\
\hline & & C. Fire Fighter Access Aperture \\
\hline 1 & C1 & Access aperture size \\
\hline 2 & C2 & Access aperture alternative \\
\hline 3 & C3 & Access aperture signage \\
\hline & & D. Fire Fighter Shaft \\
\hline 1 & D1 & Total of fire fighter shafts \\
\hline 2 & D2 & Fire stairs \\
\hline 3 & D3 & Water supply \\
\hline 4 & D4 & Shaft distance \\
\hline 5 & D5 & Fire lift \\
\hline
\end{tabular}

Then calculate the weight of each variable to get the percentage of each variable. The steps are, determine the valuation of the importance of each variable and sub-variables assisted by Interest Scale to filling in a matrix that is appropriate to the existing conditions of the fire fighting access during the survey.

After determining the valuation of interests in the variables, the next step is by examining the initial comparison (Table 6). After calculating so get the value of each variable's importance, then do comparative normalization (Table 7).

Table 6.Calculation of the Initial Matrix of Variable Interests

\begin{tabular}{ccccc}
\hline & $\mathrm{A}$ & $\mathrm{B}$ & $\mathrm{C}$ & $\mathrm{D}$ \\
\hline $\mathrm{A}$ & 1,00 & 2,00 & 2,00 & 1,00 \\
\hline $\mathrm{B}$ & 0,50 & 1,00 & 2,00 & 1,00 \\
\hline $\mathrm{C}$ & 0,50 & 0,50 & 1,00 & 2,00 \\
\hline $\mathrm{D}$ & 1,00 & 1,00 & 0,50 & 1,00 \\
\hline & 3,00 & 4,50 & 5,50 & 5,00 \\
\hline
\end{tabular}


Table 7.Comparative Normalization Matrix for Variable Interests

\begin{tabular}{ccccccccc}
\hline & A & B & C & D & $\begin{array}{c}\text { Sum in } \\
\text { Row }\end{array}$ & $\begin{array}{c}\text { Priority } \\
\text { Vector }\end{array}$ & $\begin{array}{c}\text { Temporary } \\
\text { Weight }\end{array}$ & $\begin{array}{c}\text { Final } \\
\text { Weight }\end{array}$ \\
\hline A & 0,33 & 0,44 & 0,36 & 0,20 & 1,34 & 0,34 & 1,45 & 0,34 \\
\hline B & 0,17 & 0,22 & 0,36 & 0,20 & 0,95 & 0,24 & 1,05 & 0,24 \\
\hline C & 0,17 & 0,11 & 0,18 & 0,40 & 0,86 & 0,21 & 0,92 & 0,21 \\
\hline D & 0,33 & 0,22 & 0,09 & 0,20 & 0,85 & 0,21 & 0,89 & 0,21 \\
\hline & 1,00 & 1,00 & 1,00 & 1,00 & 4,00 & & 4,32 & 1,00 \\
\hline
\end{tabular}

After calculating the initial matrix and the comparative normalization matrix for each variable interest, then calculate the weight of each sub-variable to get the weight per cent of the subvariables that have been sorted out. The comparison matrix and sub-variable normalization of variable $A$ can shows in table 8 and table 9 , variable $B$ in table 10 and table 11 , variable $C$ in table 12 and table 13 , and variable $\mathrm{D}$ in table 14 and table 15.

Table 8. Comparison Matrix of the Fire fighting Access (Variable A)

\begin{tabular}{cccccccc}
\hline & $\mathrm{A} 1$ & $\mathrm{~A} 2$ & $\mathrm{~A} 3$ & $\mathrm{~A} 4$ & $\mathrm{~A} 5$ & $\mathrm{~A} 6$ & $\mathrm{~A} 7$ \\
\hline $\mathrm{A} 1$ & 1,00 & 1,00 & 2,00 & 2,00 & 2,00 & 3,00 & 4,00 \\
\hline $\mathrm{A} 2$ & 1,00 & 1,00 & 2,00 & 2,00 & 2,00 & 3,00 & 4,00 \\
\hline $\mathrm{A} 3$ & 0,50 & 0,50 & 1,00 & 1,00 & 2,00 & 2,00 & 3,00 \\
\hline $\mathrm{A} 4$ & 0,50 & 0,50 & 1,00 & 1,00 & 2,00 & 2,00 & 3,00 \\
\hline $\mathrm{A} 5$ & 0,50 & 0,50 & 0,50 & 0,50 & 1,00 & 2,00 & 3,00 \\
\hline $\mathrm{A} 6$ & 0,33 & 0,33 & 0,50 & 0,50 & 0,50 & 1,00 & 5,00 \\
\hline $\mathrm{A} 7$ & 0,25 & 0,25 & 0,33 & 0,33 & 0,33 & 0,20 & 1,00 \\
\hline & 4,08 & 4,08 & 7,33 & 7,33 & 9,83 & 13,20 & 23,00 \\
\hline
\end{tabular}

Table 9. Sub-variable Normalization of the Fire fighting Access (Variable A)

\begin{tabular}{cccccccccccc}
\hline & A1 & A2 & A3 & A4 & A5 & A6 & A7 & $\begin{array}{c}\text { Sum } \\
\text { in } \\
\text { Row }\end{array}$ & $\begin{array}{c}\text { Priority } \\
\text { Vector }\end{array}$ & $\begin{array}{c}\text { Temporary } \\
\text { Weight }\end{array}$ & $\begin{array}{c}\text { Final } \\
\text { Weight }\end{array}$ \\
\hline A1 & 0,24 & 0,24 & 0,27 & 0,27 & 0,20 & 0,23 & 0,17 & 1,64 & 0,23 & 1,71 & 0,23 \\
\hline A2 & 0,24 & 0,24 & 0,27 & 0,27 & 0,20 & 0,23 & 0,17 & 1,64 & 0,23 & 1,71 & 0,23 \\
\hline A3 & 0,12 & 0,12 & 0,14 & 0,14 & 0,20 & 0,15 & 0,13 & 1,00 & 0,14 & 1,05 & 0,14 \\
\hline A4 & 0,12 & 0,12 & 0,14 & 0,14 & 0,20 & 0,15 & 0,13 & 1,00 & 0,14 & 1,05 & 0,14 \\
\hline A5 & 0,12 & 0,12 & 0,07 & 0,07 & 0,10 & 0,15 & 0,13 & 0,76 & 0,11 & 0,80 & 0,11 \\
\hline A6 & 0,08 & 0,08 & 0,07 & 0,07 & 0,05 & 0,08 & 0,22 & 0,64 & 0,09 & 0,66 & 0,09 \\
\hline A7 & 0,06 & 0,06 & 0,05 & 0,05 & 0,03 & 0,02 & 0,04 & 0,31 & 0,04 & 0,42 & 0,06 \\
\hline & 1,00 & 1,00 & 1,00 & 1,00 & 1,00 & 1,00 & 1,00 & 7,00 & & 7,42 & 1,00 \\
\hline
\end{tabular}

Table 10.Comparison Matrix of Water Supply (Variable B)

\begin{tabular}{cccc}
\hline & B1 & B2 & B3 \\
B1 & 1,00 & 2,00 & 3,00 \\
\hline B2 & 0,50 & 1,00 & 2,00 \\
\hline B3 & 0,33 & 0,50 & 1,00 \\
\hline & 1,83 & 3,50 & 6,00 \\
\hline
\end{tabular}


Table 11.Sub-variable normalization of Water Supply (Variable B)

\begin{tabular}{cccccccc} 
& B1 & B2 & B3 & $\begin{array}{c}\text { Sum } \\
\text { in } \\
\text { Row }\end{array}$ & $\begin{array}{c}\text { Priority } \\
\text { Vector }\end{array}$ & $\begin{array}{c}\text { Temporary } \\
\text { Weight }\end{array}$ & $\begin{array}{c}\text { Final } \\
\text { Weight }\end{array}$ \\
\hline B1 & 0,55 & 0,57 & 0,50 & 1,62 & 0,54 & 1,62 & 0,54 \\
\hline B2 & 0,27 & 0,29 & 0,33 & 0,89 & 0,30 & 0,89 & 0,30 \\
\hline B3 & 0,18 & 0,14 & 0,17 & 0,49 & 0,16 & 0,49 & 0,16 \\
\hline & 1,00 & 1,00 & 1,00 & 3,00 & & 3,01 & 1,00 \\
\hline
\end{tabular}

Table 12.Comparison Matrix of Access Aperture of Fire Fighter (Variable C)

\begin{tabular}{ccccc}
\hline & $\mathrm{C} 1$ & $\mathrm{C} 2$ & $\mathrm{C} 3$ \\
\hline $\mathrm{C} 1$ & 1,00 & 1,00 & 2,00 \\
\hline $\mathrm{C} 2$ & 1,00 & 1,00 & 2,00 \\
\hline $\mathrm{C} 3$ & 0,50 & 0,50 & 1,00 \\
\hline & 2,50 & 2,50 & 5,00 \\
\hline
\end{tabular}

Table 13.Sub-variable Normalization of Access Aperture of Fire Fighter (Variable C)

\begin{tabular}{cccccccc}
\hline & $\mathrm{C} 1$ & $\mathrm{C} 2$ & $\mathrm{C} 3$ & $\begin{array}{c}\text { Sum } \\
\text { in } \\
\text { Row }\end{array}$ & $\begin{array}{c}\text { Priority } \\
\text { Vector }\end{array}$ & $\begin{array}{c}\text { Temporary } \\
\text { Weight }\end{array}$ & $\begin{array}{c}\text { Final } \\
\text { Weight }\end{array}$ \\
\hline $\mathrm{C} 1$ & 0,40 & 0,40 & 0,40 & 1,20 & 0,40 & 1,20 & 0,40 \\
\hline $\mathrm{C} 2$ & 0,40 & 0,40 & 0,40 & 1,20 & 0,40 & 1,20 & 0,40 \\
\hline $\mathrm{C} 3$ & 0,20 & 0,20 & 0,20 & 0,60 & 0,20 & 0,60 & 0,20 \\
\hline & 1,00 & 1,00 & 1,00 & 3,00 & & 3,00 & 1,00 \\
\hline
\end{tabular}

Table 14.Comparison Matrix of Fire Fighting Shaft (Variable D)

\begin{tabular}{cccccc}
\hline & D1 & D2 & D3 & D4 & D5 \\
\hline D1 & 1,00 & 5,00 & 2,00 & 4,00 & 3,00 \\
\hline D2 & 0,20 & 1,00 & 2,00 & 4,00 & 5,00 \\
\hline D3 & 0,50 & 0,50 & 1,00 & 5,00 & 5,00 \\
\hline D4 & 0,25 & 0,25 & 0,20 & 1,00 & 3,00 \\
\hline D5 & 0,33 & 0,20 & 0,20 & 0,33 & 1,00 \\
\hline & 2,28 & 6,95 & 5,40 & 14,33 & 17,00 \\
\hline
\end{tabular}

Table 15.Sub-variable Normalization of Fire Fighting Shaft (Variable D)

\begin{tabular}{cccccccccc}
\hline & D1 & D2 & D3 & D4 & D5 & $\begin{array}{c}\text { Sum } \\
\text { in } \\
\text { Row }\end{array}$ & $\begin{array}{c}\text { Priority } \\
\text { Vector }\end{array}$ & $\begin{array}{c}\text { Temporary } \\
\text { Weight }\end{array}$ & $\begin{array}{c}\text { Final } \\
\text { Weight }\end{array}$ \\
\hline D1 & 0,44 & 0,72 & 0,37 & 0,28 & 0,18 & 1,98 & 0,40 & 2,54 & 0,42 \\
\hline D2 & 0,09 & 0,14 & 0,37 & 0,28 & 0,29 & 1,18 & 0,24 & 1,40 & 0,23 \\
\hline D3 & 0,22 & 0,07 & 0,19 & 0,35 & 0,29 & 1,12 & 0,22 & 1,26 & 0,21 \\
\hline D4 & 0,11 & 0,04 & 0,04 & 0,07 & 0,18 & 0,43 & 0,09 & 0,46 & 0,08 \\
\hline D5 & 0,15 & 0,03 & 0,04 & 0,02 & 0,06 & 0,29 & 0,06 & 0,31 & 0,05 \\
\hline & 1,00 & 1,00 & 1,00 & 1,00 & 1,00 & 5,00 & & 5,98 & 1,00 \\
\hline
\end{tabular}

So, the last stage is processing data from the results of the per cent weight of sub-variables to determine the reliability value of Cambridge the Luxurious Mall and Condominium (Table 12). 
Table 16. Cambridge the Luxurious Mall and Condominium Data Processing

\begin{tabular}{|c|c|c|c|c|c|c|}
\hline Code & Sub Variable & Weight & NK & $\begin{array}{c}\text { Sub- } \\
\text { variable } \\
\text { Value }\end{array}$ & Sum & $\begin{array}{c}\text { Variable } \\
\text { Value }\end{array}$ \\
\hline & A. Fire Fighting Access & 0,34 & & & & \multirow{8}{*}{0,89} \\
\hline A1 & Distance and travel time from the nearest fire station & 0,23 & 4 & 0,92 & \multirow{7}{*}{2,65} & \\
\hline $\mathrm{A} 2$ & Firefighting access road & 0,23 & 2 & 0,46 & & \\
\hline $\mathrm{A} 3$ & Hard-standing Availability & 0,14 & 2 & 0,28 & & \\
\hline A4 & Height of free space and slope of hard-standing & 0,14 & 3 & 0,43 & & \\
\hline A5 & Material of hard-standing & 0,11 & 3 & 0,32 & & \\
\hline A6 & The outer radius of the turn, the size, and the distance of the hard-standing & 0,09 & 2 & 0,18 & & \\
\hline \multirow[t]{2}{*}{ A7 } & Hard-standing signage & 0,06 & 1 & 0,06 & & \\
\hline & B. Water Supply & 0,24 & & & & \multirow{4}{*}{0,66} \\
\hline $\mathrm{B} 1$ & Alternative fire fighter water supply & 0,54 & 3 & 1,62 & \multirow{3}{*}{2,70} & \\
\hline B2 & Outdoor hydrant & 0,30 & 2 & 0,59 & & \\
\hline \multirow[t]{2}{*}{ B3 } & City hydrant and siamese connection & 0,16 & 3 & 0,49 & & \\
\hline & C. Fire Fighter Access Aperture & \multicolumn{3}{|l|}{0,21} & & \multirow{4}{*}{0,73} \\
\hline $\mathrm{C} 1$ & Access aperture size & 0,40 & 4 & 1,60 & \multirow{3}{*}{3,40} & \\
\hline $\mathrm{C} 2$ & Access aperture alternative & 0,40 & 4 & 1,60 & & \\
\hline \multirow[t]{2}{*}{$\mathrm{C} 3$} & Access aperture signage & 0,20 & 1 & 0,20 & & \\
\hline & D. Fire Fighter Shaft & \multicolumn{3}{|l|}{0,21} & & \multirow{6}{*}{0,59} \\
\hline D1 & Total of fire fighter shafts & 0,42 & 2 & 0,85 & \multirow{5}{*}{2,84} & \\
\hline D2 & Fire stairs & 0,23 & 4 & 0,94 & & \\
\hline D3 & Water supply & 0,21 & 4 & 0,84 & & \\
\hline D4 & Shaft distance & 0,08 & 2 & 0,16 & & \\
\hline D5 & Fire lift & 0,05 & 1 & 0,05 & & \\
\hline \multicolumn{2}{|r|}{ RELIABILITY VALUE } & & & & & 2,86 \\
\hline
\end{tabular}

From the results of the above calculations, then do compare with the value of the Reliability ValueScale (Table 13).

Table 17.Reliability Value of Fire Fighting Access

\begin{tabular}{cc}
\hline Reliability Value & Explanation \\
\hline $1,00<\mathrm{x} \leq 1,60$ & Bad \\
\hline $1,60<\mathrm{x} \leq 2,20$ & Deficient \\
\hline $2,20<\mathrm{x} \leq 2,80$ & Sufficient \\
\hline $2,80<\mathrm{x} \leq 3,40$ & Good \\
\hline $3,40<\mathrm{x} \leq 4,00$ & Excelent \\
\hline
\end{tabular}

\section{Conclusion}

After analysing the firefighter access in Cambridge the Luxurious Mall and Condominium building using the AHP (Analytical Hierarchy Process) method, this method is very useful in solving a problem in a hierarchical decision support system, pair comparison, and overall weight evaluation.

According to the results of data processing using the AHP method, the reliability value of firefighter access in Cambridge the Luxurious Mall and Condominium building is 2.86, which means that the level of firefighter access reliability is Good. While the reliability values for each variable are variable Fire Fighting Access is 2,65 which means Sufficient, variable Water Supply is 2.70 which means Sufficient, variable Fire Fighter Shaft is 2.84 which means Good, and Fire Fighter Access Aperture is 3.40 which means Good. 
According to the reliability values of firefighter access in Cambridge the Luxurious Mall and Condominium building, so are given some possible design recommendations to improve the reliability of firefighter. They are, the side that is directly bordering to the Deli river is difficult to access, and it is recommended to procure fire fighting vehicles that can access waters (streams). Besides, also place signages on the fire engine hard-standing in Cambridge the Luxurious Mall and Condominium building on the side of the road that didn't block the vehicles and pedestrians circulation. The design is flat with the road surface, in contrast, and glow in the dark while the hard-standing on the road outside the site along the outer wall of the building. Then, placing signages on firefighter access aperture on each side of Cambridge the Luxurious Mall and Condominium building on each floor by the requirements. Complete yard hydrants following specifications, as well as carry out regular maintenance on yard hydrant systems, city hydrants, siamese connections, as well as the water supplies for the prevention of fire accident. Considering a large number of users because of the mixed-use building function is recommended to provide the fire fighting lift in every firefighter shaft in Cambridge the Luxurious Mall and Condominium building. As an alternative, the fire fighting lift can use the freight elevator in the building that complies with the requirements of the fire protection system.

\section{Acknowledgment}

The results of this research are expected to be useful as a reference for the user and the provider of the highrise building, to find out the circumstances and problems on the access of firefighter as passive fire protection in the highrise building.

\section{REFERENCES}

[1] M. Ahrens, High-rise Building Fires, US: National Fire Protection Association, 2006.

[2] Indonesia, Persyaratan Teknis Sistem Proteksi Kebakaran pada Bangunan Gedung dan Lingkungan, Jakarta: Peraturan Mentri Pekerjaan Umum No. 26, 2008.

[3] Indonesia, Pedoman Teknis Manajemen Proteksi Kebakaran di Perkotaan, Jakarta: Peraturan Menteri Pekerjaan Umum No. 20, 2009.

[4] B. S. Nasional, SNI 03-1735-2000: Tata Cara Perencanaan Akses Bangunan dan Akses Lingkungan untuk Pencegahan Bahaya Kebakaran pada Bangunan Gedung, Jakarta: Badan Penerbit PU, 2000.

[5] Indonesia, Bangunan Gedung, Pasal (12), Jakarta: Peraturan Menteri Daerah No. 5, 2009. 
[6] "Emporis High-rise Building (ESN 18727)," 2000. [Online]. Available: https://www.emporis.com/building/standard/3/high-rise-building. [Diakses 7th March 2018].

[7] T. L. Saaty, The Analytical Network Process: Decision Making with Dependence and Feedback, RWS Publ., 2001. 